\title{
Higher Education in the Middle East and India: Overview and Two Programs Created to Educate Global Business Leaders in Emerging Markets
}

\author{
Van R. Wood, Nanda Rangan \\ Virginia Commonwealth University, Richmond, USA \\ Partha Gopalakrishna \\ iGate Global Solutions Limited, Richmond, USA
}

\begin{abstract}
Globalization, no matter how one comprehends it, has lifted the social and economic welfare, both real and potential, of millions of people around the world. Middle-class (and higher) segments of emerging markets have grown and prospered from the opportunities brought on by globalization. Two such markets, the Middle East and India, while distinct in many ways, offer insights into globalizations inter-play (action and reaction) with higher education. This paper, based on the premise that education is a primary correlate with the benefits of globalization, features Middle Eastern and Indian realities in the context of university education. The most significant dimensions of such education from a business perspective are noted in the context of today's globalized commercial environment. The paper concludes with overviews of efforts by the authors to create an Executive Master of Business Administration (EMBA) degree with partners in Cairo, Egypt, and a Master of Science in Global Marketing Management and Finance (MS-GMM-Fin.) with partners in Bangalore, India.
\end{abstract}

Keywords: global business leadership, higher education international partnerships, emerging markets

\section{Introduction}

Globalization remains a two-sided phenomenon, one offering great promise for social and economic development on a grand scale, and the other portending a degradation of human welfare, if not spirit (Wood \& Makhani, 2004). The forces behind globalization (democratization of technology, finance and information) "that intensify the interaction and integration among cultural, political, business and intellectual elements”, in our world (Ali, 2000, p. 84), continue almost unabated. And the debate goes on, with proponents touting globalization as the triumph of free-market capitalism over closed-market, centrally planned economic systems (communism and to a lesser degree socialism), and the emancipation of the consumer from state controlled

\footnotetext{
Van R. Wood, Ph.D., Professor of International Marketing and Philip Morris Endowed Chair in International Business, Department of Marketing, Virginia Commonwealth University.

Nanda Rangan, Ph.D., Department of Finance, Insurance and Real Estate Chair, Virginia Commonwealth University.

Partha Gopalakrishna, graduate student, iGate Global Solutions Limited.

Correspondence concerning this article should be addressed to Van R. Wood, 301 West Main Street, Richmond, Virginia, 23284.E-mail: vrwood@vcu.edu.
} 
economic tyranny (Friedman, 1999). Opponents argue that globalization ultimately leads not only to the destruction of cultural identities but also to the economic, political and social subjugation of underdeveloped nations to more dominate counterparts, particularly the United States (Klein, 2001).

All in all, not much has changed over the last 20 years with respect to the two viewpoints. Two things appear to remain mutually agreed upon and constant with respect to both sides perception of globalization, those being: (1) globalization is not going away (and no other model or theory explaining current human development and related challenges is anywhere close to usurping it); and (2) the foremost key to any individual, country or region benefiting from globalization lies with a solid foundation in education (Freidman, 2005).

This paper explores the role of education in the era of globalization from a Middle East/Arabic Region and India perspective and presents related insights through: (1) a brief overview of the educational milieu in both markets (the Middle East and India); (2) a summary of "global business leadership" needs and the characteristics of global business leaders in the era of globalization; (3) a delineation of an Executive Master of Business Administration (EMBA) program in Cairo, Egypt and a Master of Science (MS) program in Global Marketing Management and Finance in Bangalore, India that are a response to global business needs in both the Middle East (specifically Egypt) and India (specifically, Bangalore); and (4) a look at the future, including the challenges of developing and implementing an EMBA with partners in the Middle East and an MS with partners in India and what is envisioned when higher level business education prepares present and future managers to effectively compete in the globalized business environment of today.

\section{A Brief Overview of the Educational Milieu in the Middle East}

Human capital formation is receiving increased attention from policy makers and scholars interested in promoting economic and social progress in developing regions of the world (UNICEF, 2000; World Bank, 2003). Education models which focus on social and economic growth stress the importance of investment in knowledge, including and perhaps particularly higher education, as a critical factor in creating business dynamism in developing regions (The Middle East Policy Council, and The Stanley Foundation, 2002). Specialists have long argued that education should form a principal component in any development strategy (Abdeljalil, 2004), and the Arab language region of the world is not different.

The Arabic region of the world stretches from the Atlantic Ocean to the Arab-Persian Gulf. It encompasses the Middle East and North Africa and the cultural and historic commonalities of the countries that exist here share many common themes. In particular, Islam as the main religion and Arabic as the predominant language are key factors in the cultural identity of the region. Historically, European colonization during the nineteenth and the first half of the twentieth centuries shaped much of the regions shared psyche. When independence arrived to the region, in the later half of the twentieth century, a strong economic, cultural and political dependence on developed countries remained and remains today (Gould, 1993).

As noted, while many factors shape a countries' (and region's) development and growth potential (e.g., natural resources, government structure, legal-business environment, shared values), education of its citizenry it perhaps the most important ingredient, particularly in this era of globalization (Friedman, 1999, 2005). While all countrys' educational history and contemporary realities are different, there are several similarities among the Arabic speaking countries, which provide insight into the need for educational systems in this region that will 
allow it to fully engage in the global business environment that is driving development is so many other regions of the world, including China, India, Brazil, Eastern Europe and others. While the details of these similarities are outside the scope of this paper, in essence they amount to the following (see Said, 1993):

(1) While compulsory education was initiated by European colonizers in the Arabic region, access was restricted for natives in order to maintain colonial power (by controlling access to governmental administration positions) and to weaken nationalism.

(2) The alternative Koranic system of education, which was taught in Arabic and emphasized Islam and a Muslim upbringing, was generally opposed to Western hegemony both cultural and economic. Although modern schooling was not rejected by all, nor denied to all, the two forces of denied access to education during the colonial period and rejection of "infidel" influences by local Koranic schools (which is still prevalent in some areas of the region), combined to hinder the investment in human capital needed to compete in the modern world (Akkari, 1999).

(3) Today (and for much of the second half of the twentieth century), while education has improved significantly and is accepted by most as an investment with long-term benefits to individuals and the public at large, population growth in the Arab countries (among the highest in the world), creates major challenges (overcrowding, limits access to educational resources) in providing basic, much less advanced education to the people of the region (Watkins, 1999, UNICEF, 2004).

(4) Despite a significant advancements in formal education in the countries of the Arabic region during the last decades, the connection between education and employment is still lacking (this is particularly apparent in Egypt—see Fergany, 1995). Without further advancements to tie the region to the global economy and its vast markets, both unemployment and under-employment is expected to be exacerbated (Friedman, 2005).

(5) Many educational systems in the region suffer from bureaucratic structures that emphasize a top down approach to learning, and many in charge of education have implement rigid curriculum centered on memorization. Today's students must be taught the skills that are needed to function effectively in tomorrow's world. Moreover, they must be taught the problem-solving, cooperation and critical thinking skills that are needed to build democracy and citizenship (Akkari, 2004).

The above five generalizations (colonization's early effect on education, the Koranic system's tendency to oppose Westernization and Western education, the challenges of population growth and education of the masses, the gap between being educated and being fully employed, and the focus on memorization rather than critical thinking in Arabic education) have led to a call for new initiatives in the nature and delivery of education in the Arab world. This call has been particularly focused on higher education.

The Middle East Policy Council 2008 has stated that education is a key factor in Arabic region's economic development and that the United States (and other developed countries) can play a positive role by promoting expanded access to progressive higher education for all Arab students. However, since September 11, 2001, fewer students from the region are attending colleges and universities in the United States, as they are often treated with great suspicion. U.S. immigration laws and the high cost of American education have also contributed to the decline in the number of Middle Eastern students who apply to higher educational institutions in America. The council urges the expansion of education between the Middle East and the West by supporting and building on existing American universities in the Middle East, such as the American University of Beirut and 
the American University of Cairo and by offering new, innovative programs that would allow the region to embrace the opportunities that exist in the globalized business world.

\section{A Brief Overview of the Educational Milieu in India}

The private education market in India is estimated to be worth $\$ 40$ billion now and is expected to grow to $\$ 50$ billion by 2015 (Sheikh, 2010). Fifty-five percent of India's middle class families save for the education of their children. India's higher education system, with more than 13 million students, is the world's third largest, however it currently only educates around 12 percent of the school age group, well under China's 27 percent (Altbach, 2010). Also, according to industry estimates, only a quarter of all graduates from Indian schools are employable and about $80 \%$ of job seekers in employment exchange are without any professional skills (Magtech Management Institute, 2010). In short, India is suffering from a massive shortage of skilled manpower.

The history of education in India can be traced as far back as the 3rd century BC. Even before letters were developed and writing was formulated, education was imparted from one generation to another orally. Scholars and religious leaders used temples or their own abodes as the schools for imparting education. This method of education was called the Gurukul system, and involved young men staying with their Guru (teacher) during their adolescent period and learning the skills required to prosper in life. Later with the spread of Buddhism in the continent, world famous educational institutions like Nalanda and Takshashila were established taking the education imparting process to a new level. Nalanda has been called "one of the first great universities of recorded history" and was one of the world's first residential universities. Till its downfall in the 12th century international scholars from the surrounding countries were educated there and at its peak time the university had over 10,000 students and 2,000 teachers (World Bank, 2010).

By the 10th century, India had a sophisticated system of mathematics and science and impressive arrays of inventions and discoveries. The invention of zero, algebraic abbreviations, decimal numbers, differential equation, Pythagorean Theorem were just few of the contributions that India made to the world of education during this period. In the 11th century Muslim leaders (invaders) created the elementary and secondary school system, which eventually lead to the advent of universities in many Indian cities. Later, with the British invasion and colonization, the English language became a part of the Indian higher education curriculum and since then education in the country has progressed steadily forward albeit unevenly. With this "westernization" of the education system, India has steadily opened the doors to a broader sect of students from across the world (World Bank, 2010). However, a number of significant challenges exist, including:

(1) Access to primary education: While India understands that primary education is critical for its growth and development, making such education available to the masses has been an ongoing challenge. According to the 2001 census, only 59.4\% of rural India is literate in comparison to the $80.3 \%$ in urban India (World Bank, 2003). The challenge is not just educating the masses but also providing quality education to them as the typical rural area is plagues by unqualified teachers, high student-teacher ratios, inadequate teaching facilities, poor infrastructure and downright poverty.

(2) Access to secondary education: secondary education in india is likewise critical to the country's future as it acts as the bridge between primary and higher education. While there are 88.5 million children in the age group of 14-18 only 31 million of those are attending schools. Another key challenge related to access is that many 
students study in their native language (16 are officially recognized in India) both in primary education and secondary education. This hinders many from participating in higher education where the medium of teaching is English (Wapedia, 2010).

(3) Access to higher education: With over 300 universities and 15,600 colleges spewing out 2.5 million graduates each year, India trails only the US and recently China in terms of volume (Basu, 2006). Higher Education in India has grown significantly since independence in 1947, and unlike primary and secondary education, private and public institutions of higher education have relatively modern facilities. Likewise, significant "democratization” in the 1960's facilitated greater accessibility of higher education to the general public. This expansion was however done in phases, with the first phase providing government support to many more citizens to pursue higher education, however during the second phase (the 1990's—up to the present time) private-commercial education providers became the dominate players in providing higher education and this has transferred the cost and responsibility of education to parents and children (Agarwal, 2009). Driven by globalization and the resulting growth prospects for the Indian economy, the demand for higher education is constantly increasing and while the government and the private sector continue to create new strategies for expanding higher education options, the supply is still woefully inadequate and high quality and affordable higher education for the masses remains elusive (Altbach, 2010).

(4) Corruption: Commercialization of India's higher education has led to another growing problem namely corruption. It is estimated that Indians spend U.S. \$ 5.6 billion in bribes every year, and the amount spent in education bribes exceeds U.S. \$ 880 million per year (Surapaneni, 2010). Likewise, individuals in positions of authority who are responsible for granting approvals for medical/engineering and business institutions are typically businessmen or politicians who often look at benefiting financially from the admission process. This corruption in turn leads to a cycle of failures in the functioning of the country's education system wherein individuals who pay to gain admissions into institutions of higher education resort to unfair and unethical means to recover the money back quickly when given an opportunity (Jayaprakash, 2009). Similarly, another failure that is commonly seen is absenteeism by teachers and professors. A UNICEF (2004) study reveals that absenteeism in India is $25 \%$ (second only to Uganda). Absenteeism has becomes a method adopted by teachers to coerce students to enroll in private tutoring. Most Indian institutions of higher education depend on individual teachers assessments and it is an unspoken fact that students who are privately tutored are more likely to get a higher assessment scores from their private tutor.

Other challenges are apparent within the system of higher education in India, including those related to the Caste structure (quotas) and religion (Surapaneni, 2010). Likewise, it is a fact Indian education, in general, stresses theoretical knowledge and memorization and lack case study methods, team projects, and a focus on boundary spanning and critical thinking to deal with complexity (as in the West, which tends to impart practical—problem-solving knowledge among students), all of which leads Indian graduates to be less ready to meaningfully contribute to the workforce without years of training in private companies or other types of organizations (Khemka, 2006; Altbach, 2010; UNICEF, 2006). In summary, India needs to improve the quality of education and develop higher standards across all levels of education. While many ideas on how best to deal with these needs exist, one with idea with significant potential is for India to embrace partnerships with premium foreign institutions that can not only change the culture of learning at Indian institutions of higher education but 
can also offer students contacts with their counterparts around the world that would give them the critical linkages thought to be strongly correlated to success in this era of globalization (Magtech Management Institute, 2010; Altbach, 2010). Today, however almost all of India's universities and more than 25,000 undergraduate colleges are, by international standards, mediocre at best (Census India, 2010).

Given the generalizations noted above and based on the subsequent related calls for innovative programs to be developed with Western partners, both in the Middle East and India, this paper turns to what innovative education should focus upon and the attributes that it should strive to instill in those being educated for top positions in business. More specifically, we focus on those being educated to assume the responsibility of positioning their firm or organization to compete effectively in the global business arena.

\section{Global Business Leadership Needs and the Characteristics of Global Business Leaders-Insights for Higher Education}

In his seminal book Winning the Global Game: A Strategy For Linking People and Profits, Rosensweig (1998) outlines the realities of globalization and presents a cogent picture of where global economic growth will be, and the key ingredients for organizations to embrace in seeking such growth. In short, while the vast majority of current wealth generation occurs in the Northern Hemisphere (e.g., the U.S., Europe, Japan), the majority of such in the future will take place in the Southern Hemisphere (Asia, Latin America, the Middle East, Africa). His overriding theme for long-term planners (global business leaders) is to prepare for this reality by looking seriously at expanding their global focus to include both current and future growth areas in their market portfolios.

Rosensweig, like others (Friedman, 1999, 2005), also notes that serious "preparation” for "playing” successfully in the globalized business environment implies having the necessary human intellectual capital in place in one's organization (and one's society). If organizations and societies are to not only survive but truly prosper in the 21st century, then they must invest in programs that create the traits and characteristics that competitive global managers and executives must possess. The need for skilled individuals who can capitalize on the developing global opportunities, while avoiding the pitfalls and hazards inherent in today's volatile world has never been more apparent.

The central question thus becomes-What are the key capabilities and attributes that organizations must consider in applicants when they want to promote or hire individuals in today's interconnected economies? What should the 21st century global business executive look like? While Rosensweig articulated 12 needed competencies of a global manager which ran the gamut from possessing multicultural competencies to personal traits of strong integrity, elevated moral character, solid ethical values, considerable flexibility and energy, advanced communication skills and command of information systems and several languages, others cast this issue in broader terms.

Andrews and Tyson (2004), surveyed over 100 executives in more than 20 countries in order to identify the knowledge, skills an attribute that rising business leaders need to possess in order to succeed in the 21st century, and those that should be featured in executive education programs. The findings of their study pinpointed the need for "more thoughtful, more, aware, more sensitive, more flexible, more adaptive managers, capable of being molded and developed into global executives” (Andrews \& Tyson, 2004, p. 2). To get to this point, executive 
education had to be first and foremost, global in outlook. Second, it had to go beyond the traditional passive transfer of theoretical knowledge to the application of practical knowledge. It had to be more action oriented. And third, it had to be more multidisciplinary and integrated in terms of content.

The key tests, resulting from Andrews and Tyson's study, to whether executive education was successful was the degree to which specific knowledge, skills and attributes were present in an educated manager. Knowledge, the foundation of global business capabilities, was defined as the base information need by managers in the areas strategy, economics, decision sciences, accounting, marketing, finance and management. Advanced knowledge was defined as the integration of these areas such that holistic insight is gained (i.e., where the whole is greater than the sum of the parts). For example, a knowledgeable global executive, when asked-What does it take to build a global brand?-Would be able to draw from the multitude of disciplines in which he or she had been expose, and then integrate those disciplines and approach the issue from a broader, deeper and more impactful perspective.

Skills, or practical abilities, were defined as "learning acquired through the repeated application of knowledge”. Skills are applied management and include decision-making, project management, teambuilding, performance management, talent assessment, and cultural sensitivity. Needed skills are global and complex and require professional rather than ad hoc training. According to Andrews and Tyson, a "skilled" global manager, when charged with building a multi-cultural, world-wide marketing team, would display an array of practical abilities leading to a seamless blend of motivated, connected and loyal colleagues.

To Andrews and Tyson (2004), global managerial attributes are more akin to Rosensweig’s 12 competencies, as they represent individual qualities or characteristics and behaviors necessary for leadership. While these can be discussed and examined in an executive education venue, they typically are acquired at a later stage of an executive's career. The include self-confidence, curiosity, intuition, judgment, a passion for excellence and integrity or the "ability to remain true to clearly expressed values" (Andrews \& Tyson, 2004, p. 6). Again for example, a well developed global manager, when confronted with the meaning and significance of integrity across multiple cultures, would be able to call upon his or her developed attributes and realize that integrity is not culturally specific, but rather can be globally defined, and must be consistently reinforced in any enterprise be it global or local.

In sum, business education must be global, it must move beyond traditional, functional silos and be integrated and interdisciplinary, and it must be action oriented. At this stage, the issue becomes-What type of program(s) might meet these requirements? And more specifically, what type of program(s) might be particularly suited for the environment of the Middle East and Indian market? To address these issues, we turn to two programs being developed as a response to global business needs by the authors, including: (1) an Executive Master of Business Administration (EMBA) program with partners in Cairo, Egypt; and (2) a Master of Science (MS) in Global Marketing Management and Finance with partners in Bangalore, India.

\section{An Executive Master of Business Administration (EMBA) in Cairo, Egypt}

In August of 2003, Virginia Commonwealth University, School of Business (VCU—based in Richmond, Virginia, USA) and Helwan University, Faculty of Commerce and Business Administration (HU—based in Cairo, Egypt) submitted a grant proposal to the Binational Fulbright Commission for Educational and Cultural 
Exchange between the USA and ARE under the Commission's University Partnership Program for purposes of forming a long-term partnership to create an Executive MBA Program in Egypt. The grant was accepted and the partnership now brings together two major universities to benefit each institution by further internationalizing their business curricula. The underlying goal of this partnership is to provide an enhanced environment for students, faculty, and business communities to better meet the challenges and seize the opportunities offered in the globalized environment of the 21st century.

The program is being designed to focus on "cutting-edge" integrated EMBA knowledge, skills and attributes related to areas of study such as corporate planning and strategy, team building and leadership, quantitative and qualitative information analysis, organizational culture, productivity and innovation, marketing strategy, and the global challenges of the 21st century. It is a program guided by and intended to be responsive to the realities of the Arabic region and the needs of business leaders as described previously. The following provide a brief summary of the key dimensions related to the proposed Executive MBA Program in Cairo, Egypt.

The VCU-HU Executive Master of Business Administration program (EMBA) in Cairo, Egypt, is being developed such that it is as similar, as possible, to the current on-campus program at VCU, but tailored to the region in which it will exist. Figures 1 and 2 list a number of ideas central in the program.

\section{vcubusiness}

\section{VCU-HU Executive MBA in Cairo}

- An innovative executive education experience for employees in key leadership positions

- A 17-month-long intensive graduate study program delivered by graduate faculty from both the U.S. and Egypt

- An opportunity for you to grow the best talent within your organization by allowing participants to advance in their careers as they pursue a world-class educational experience

- The best networking opportunity for "fast track" executive-level managers

Figure 1. VCU-HU executive MBA in Cairo.

\section{vcubusiness}

\section{Unique Program Features}

- Diverse perspectives of business theory and practice guide the executive training and prepare managers for senior-level executive decisions

- Lectures and active in-class discussions increase the level of knowledge and ability of participants to recognize, analyze, and solve problems across functional areas of organization

- Exercises and assignments improve written and verbal communication skills of program participants, including interpersonal interaction and team behaviors

- Group activities develop long-term working relationships and strengthen participants’ professional networks

Figure 2. Unique program features.

The Egyptian based program will consist of seven modules (39 credit hours in total). Each module 
represents an integration of traditional "silos" of subjects, around specific themes. As noted previously, "silos" leaves much to be desired in terms of real student understanding of and focus on the critical issues that correlate with success business in today's global business arena. Figures 3, 4 and 5 provide examples on this "modularized" integration and related focus. The 17-month program will be preceded by prerequisite "mini-camps" which allow managers to upgrade their current knowledge of business basics (accounting, finance, economics, quantitative analysis) such that they are fully prepared to engage the content of the program's seven modules. The program schedule is designed to use both face-to-face lectures/seminars and cutting edge technology (video-conferencing and Internet-based learning tools-Blackboard at VCU), and is structured to allow executives and managers to continue with their careers and jobs, while studying in the program. It is also designed to allow VCU and HU faculty to participate in the program without interfering with their existing university obligations. Figures 6 and 7 and Tables 1 and 2 provide details related to these areas of the program.

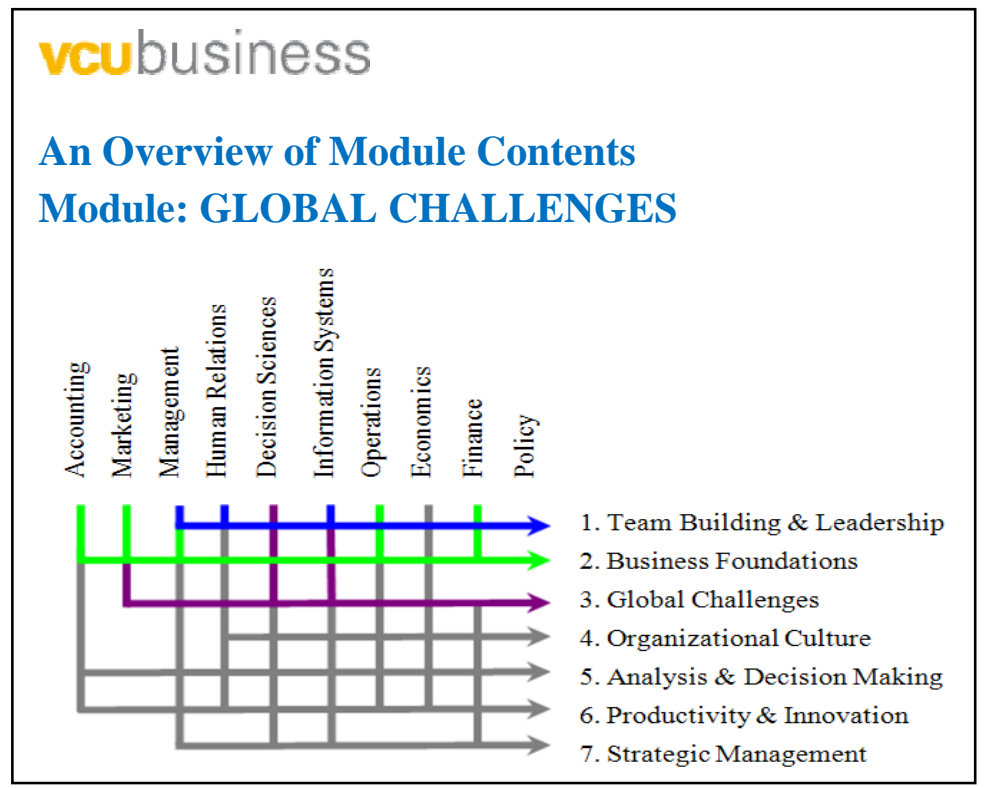

Figure 3. An overview of module contents.

The program quality and content will be the responsibility of assigned VCU and HU faculty member designated as "VCU-HU EMBA in Cairo Program Coordinators". The Program Coordinators will be responsible for the overall integration and quality of all modules. Each module will have one VCU and one HU faculty member designated as "Module Coordinators". Module Coordinators will be responsible for the selection and integration of materials and faculty/speakers in their respective modules. In addition, each module will have one additional VCU and HU faculty member who will provide assistance to the Module Coordinators. The program will have a dedicated faculty of 14 professors from VCU and a similar number of faculty from HU. These faculty, originating from the traditional academic disciplines (accounting, marketing, finance, management, economics, information systems) will be integrated into given modules, and will integrate their lectures, cases, student-team assignments and other teaching options such that traditional "silos" of knowledge are broken down, and interdisciplinary learning takes place. Collectively, the faculty will meet the requirements for program accreditation as dictated by relevant accreditation associations (including U.S. based AACSB and SACS, and corresponding Egyptian accreditation bodies). 


\title{
vcubusiness
}

\section{Descriptive Overview \& Business Applications}

\author{
Module 5-Global Challenges
}

This module deals with how organizations respond to global competition. Topics include: global markets with emphasis on the European Union, Latin \& Asian markets, accounting and finance for international operations, cultural awareness and strategies for international competition.

\section{In Module 5 you learn:}

- How companies gain and sustain competitive advantage in global markets

- The political, economic, cultural, technological, and legal environment in major regions of the world and how that environment impacts business opportunities

- Skills to deal with challenges presented by cross-cultural differences

- Forces that impact global financial markets and business opportunities they drive

- Accounting reporting and disclosure requirements around the world

- Marketing strategy applied to international market selection and entry

- Alliance building for long-term competitiveness in the global arena

Figure 4. Descriptive overview and business applications of module 5.

\section{vcubusiness}

\section{Descriptive Overview \& Business Applications}

\section{Module 2-Analysis and Decision Making}

This module examines the tools for decision-making that are available to managers. Topics include measurement, cost and managerial accounting, advanced demand estimation, marketing management, segmentation, database management systems, regression, experimental design, financial tools for measurement, and linear programming.

\section{In Module 2 you learn:}

- How managerial decision making is influenced by both quantitative and qualitative information

- How to improve decision making ability by applying systematic analytical and statistical procedures

- The role of organizational learning in bringing about change

- Interdependence among an organization's functional disciplines and the impact of these relationships on decision making and innovation

- The four goals of economics and how monetary and fiscal policy addresses these goals, the concepts of time value of money, discounted cash flow and risk

- Evaluation of financial assets and capital projects; projecting the value of bonds, preferred stock, and common stock; and analysis of capital projects, incremental cash flows, and the risk/trade-off

- Marketing as a managerial process involving strategic decision making to adapt to environmental uncertainties

- The analysis, planning, implementation, and control activities that comprise marketing management

- The marginal analysis decision rule for determining optimal output and how competitive structure within markets influences price and output decisions

- The principles, logic and procedures of demand and estimation using regression techniques

Figure 5. Descriptive overview and business applications of module 2. 


\begin{tabular}{|c|c|}
\hline \multicolumn{2}{|c|}{$\begin{array}{l}\text { VCUbUSinesS } \\
\text { VCU-HU Executive MBA Program Structure } \\
\text { Prerequisites: Mini camps, accounting/finance, statistics/math }\end{array}$} \\
\hline $\begin{array}{l}\text { First Semester } \\
\left.\text { August (1 }{ }^{\text {st }} \text { week) - December ( } 2^{\text {nd }} \text { week }\right) \\
\text { Module 1: Team Building and Leadership } \\
\text { VCU-HU EMBA 601, VCU-HU } 601 \\
\text { Module 2: Analysis and Decision Making } \\
\text { VCU-HU EMBA 604, VCU-HU EMBA 605, } \\
\text { VCU-HU EMBA 606 }\end{array}$ & $\begin{array}{l}\text { Second Semester } \\
\left.\left.\qquad \text { December ( } 3^{\text {rd }} \text { week }\right)- \text { May ( } 3^{\text {rd }} \text { week }\right) \\
\text { Module 3: Organizational Culture } \\
\text { VCU-HU EMBA } 608 \\
\text { Module 4: Business Foundations } \\
\text { VCU-HU EMBA } 603\end{array}$ \\
\hline $\begin{array}{l}\text { Third Semester } \\
\text { May }\left(4^{\text {th }} \text { week }\right)-\text { August }\left(1^{\text {st }} \text { week }\right) \\
\text { Module 5: Global Challenges } \\
\text { VCU-HU EMBA } 607\end{array}$ & $\begin{array}{l}\text { Fourth Semester } \\
\left.\qquad \text { August }\left(2^{\text {nd }} \text { week }\right)-\text { December ( } 3^{\text {rd }} \text { week }\right) \\
\text { Module 6: Productivity and Innovation } \\
\text { VCU-HU EMBA 609, VCU-HU EMBA } 610 \\
\text { Module 7: Strategic Management } \\
\text { VCU-HU EMBA 611, VCU-HU EMBA 612, } \\
\text { VCU-HU EMBA 613 }\end{array}$ \\
\hline
\end{tabular}

Figure 6. VCU-HU executive MBA program structure.

As with the EMBA Program at VCU, the VCU-HU EMBA Program in Cairo, Egypt, will employ a number of executive and/or professional guest speakers from outside the academic community in each module when appropriate. These speakers will be recruited and supervised by the VCU-HU Program Coordinators and Module Coordinators and will provide global, action-oriented and integrated business insights based on their specific experiences. Guest speakers could originate from the US business/government community and interact with the EMBA students in Cairo either through video conferencing or web-based tools such as blackboard, or they could be come from the Egyptian, Middle Eastern or other international business/government communities and provide guest lectures at the Cairo facilities. The goal is to bring together, for each module and the program as a whole, a mix of high quality faculty from both VCU and HU and a significant group of guest speakers from relevant professional communities such that a superior quality Executive MBA education can be realized.

All VCU-HU EMBA Egypt program assessments, including the overall program and faculty quality, program updates and changes, and student learning levels, will reflect those currently in place for the on-campus at the VCU EMBA Program in Richmond, Virginia. These assessments, will however, but adapted to the realities that exist in the Arabic business environment. Faculty teaching in the VCU-HU EMBA Egyptian program will collectively meet the requirements for program accreditation as dictated by relevant accreditation associations (AACSB, SACS). 
The VCU-HU program is currently on hold as political unrest and administrative changes at both institutions have delayed implementation of the undertaking. Both institutions are optimistic that the future will bring this promising partnership and program to fruition.

\section{A Master of Science in Global Marketing Management and Finance in Bangalore, India}

In January of 2010, Virginia Commonwealth University, School of Business (VCU-Richmond, Virginia) and Christ University (CU-Bangalore, India) signed a Memorandum of Understanding (MOU) articulating their partnership and specific educational program that would offer Indian graduate students the opportunity to pursue an Master of Business Administration (MBA) degree from CU and a Master of Science in Business (MS) degree from VCU.

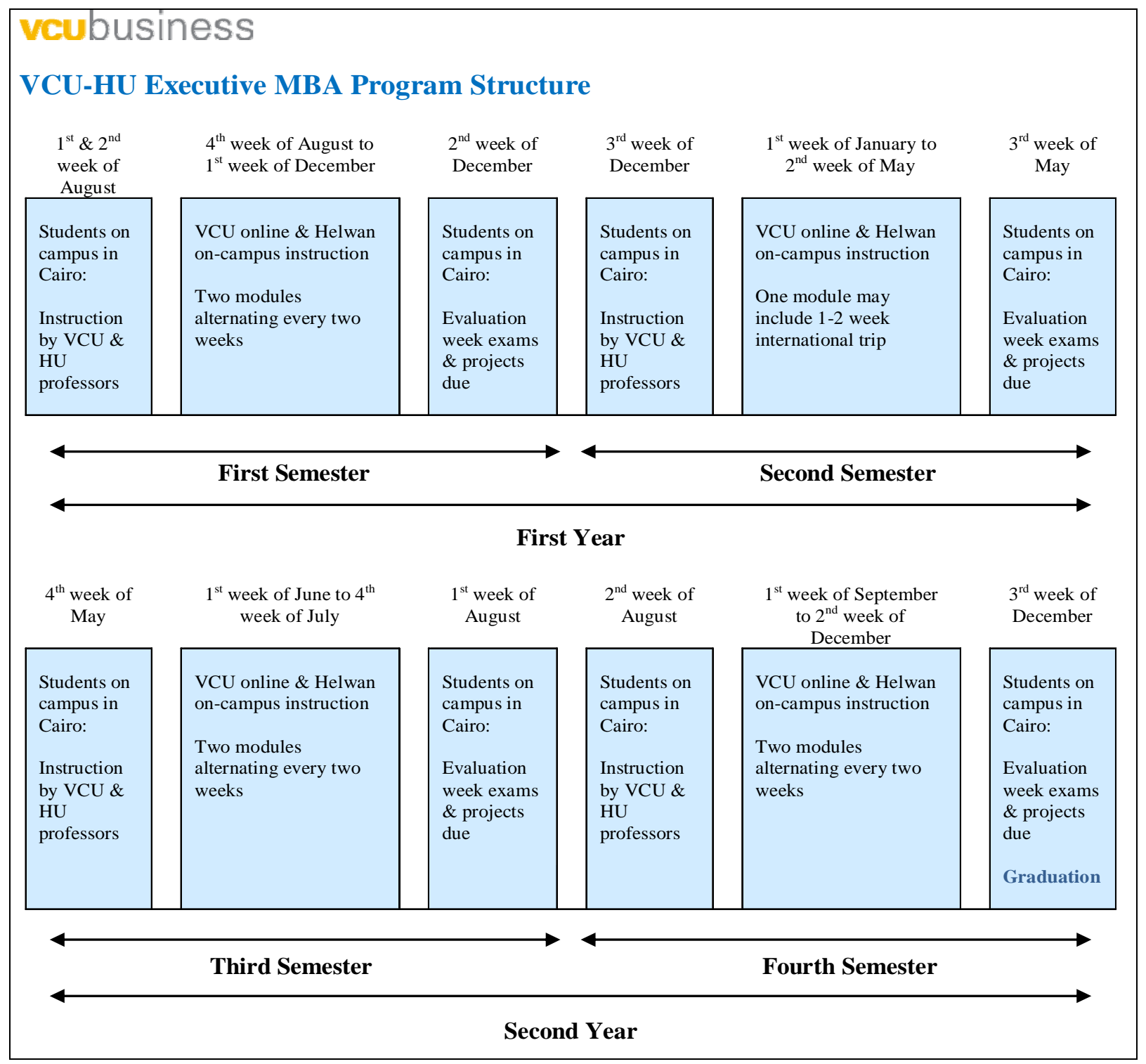

Figure 7. VCU-HU executive MBA structure continued. 
Table 1

VCU-HU Executive MBA Program Sample Delivery of On-Campus Sessions in Cairo

\begin{tabular}{|c|c|c|c|c|c|c|c|}
\hline \multirow{3}{*}{$\begin{array}{l}\text { Thursday } \\
\text { August } 3\end{array}$} & \multicolumn{3}{|c|}{ Module 1} & \multicolumn{4}{|c|}{ Module 2} \\
\hline & Friday & Saturday & Sunday & Monday & Tuesday & Wednesday & Thursday \\
\hline & August 4 & August 5 & August 6 & August 7 & August 8 & August 9 & August 10 \\
\hline 9:00-11:00 & & 9:00-11:00 & & 9:00-11:00 & 9:00-11:00 & 9:00-11:00 & 9:00-11:00 \\
\hline $11: 15-12: 45$ & & $11: 15-12: 45$ & & 11:15-12:45 & 11:15-12:45 & 11:15-12:45 & $11: 15-12: 45$ \\
\hline Lunch Break & & Lunch Break & & Lunch Break & Lunch Break & Lunch Break & Lunch Break \\
\hline 2:00-3:30 & $2: 00-3: 30$ & $2: 00-3: 30$ & 2:00-3:30 & $2: 00-3: 30$ & 2:00-3:30 & $2: 00-3: 30$ & $2: 00-3: 30$ \\
\hline $4: 00-6: 00$ & $4: 00-6: 00$ & $4: 00-6: 00$ & $4: 00-6: 00$ & $4: 00-6: 00$ & $4: 00-6: 00$ & $4: 00-6: 00$ & $4: 00-6: 00$ \\
\hline
\end{tabular}

Table 2

An Example of Delivery of VCU-HU Executive MBA Program VCU Online and Helwan On-Campus Instruction Schedule 4th Week of August to 2nd Week of December, 2006

\begin{tabular}{lll}
\hline Dates & Module 1 & Module 2 \\
\hline August 21-27 & $\mathrm{X}$ & \\
August 28-September 3 & $\mathrm{X}$ & $\mathrm{X}$ \\
September 4-September 10 & & $\mathrm{X}$ \\
September 11-September 17 & & \\
September 18-September 24 & $\mathrm{X}$ & \\
September 25-October 1 & $\mathrm{X}$ & $\mathrm{X}$ \\
October 2-October 8 & & $\mathrm{X}$ \\
October 9-October 15 & & \\
October 16-October 22 & $\mathrm{X}$ & $\mathrm{X}$ \\
October 23-October 29 & $\mathrm{X}$ & $\mathrm{X}$ \\
October 30-November 5 & & \\
November 6-November 12 & & $\mathrm{X}$ \\
November 13-November 19 & $\mathrm{X}$ & $\mathrm{X}$ \\
November 20-November 27 & $\mathrm{X}$ & $\mathrm{Exams}$ \& Projects Due \\
November 28-December 3 & & \\
December 4-December 10 & & Exams \& Projects Due \\
December 11-December 17 & &
\end{tabular}

Participating students would study for the first year of this program at CU and the second year (2 semesters) at VCU. Upon completion of the program, participating students would receive a Master of Business Administration (MBA) degree from CU and a Master of Science (MS) in Business degree from VCU (with a concentration in either Global Marketing Management or Finance). Though the program is still developing, related details include:

(1) Value proposition to participating students:

- Dual degree program; MBA from CU and MS from VCU-SOB;

- Cross cultural exposure-India and USA;

- Two semester educational experience at VCU Campus, Richmond, Virginia;

- Opportunity to experience world class education, technology and infrastructure at VCU.

(2) Proposed number of participating students:

- Maximum: 80-100 Students (40-50 in each MS Degree Option at VCU); A minimum of 25 students is 
required in each program.

(3) Profile of participating students:

Participating students will have been accepted into CU MBA program (and thus will possess an undergraduate college degree), and upon review by VCU Admissions will be accepted into the VC-MS Degree program (admitted students, upon arriving at VCU, will have completed one year of graduate coursework at CU, which will accepted as fulfillment of the VCU business foundation coursework requirements for the VCU MS Degree).

\section{CU-MBA, VCU-MS Dual Degree Program Overview}

The CU course offering are shown as the first year of the program-Terms I, II, and III (see Table 3). The VCU MS Degree program (with concentration options of global marketing management or finance) requires the completion of approximately 10 courses. The first two courses of this requirement will be taught in facilities provided by CU in Bangalore, India_-Term IIIa and IV_-Table 4 below. Eight additional courses would be taught by VCU faculty at VCU in Richmond, Virginia, USA during a 2-semester period-Term V and VI-Table 5 below. A summary of the proposed programs delivery schedule involving both CU and VCU is shown in Table 6 .

Table 3

Proposed CU Component

\begin{tabular}{lll}
\hline Terms & Courses offered & Comments \\
\hline & Information Technology for Management & \\
& Organization Behavior I & As per CU Syllabus \\
Term I & Mathematics \& Business Statistics & \\
(June 1-Aug. 31) & Financial Accounting & \\
& Managerial Economics I & \\
& Principles of Management & \\
& Management Communication \& Case Studies & As per CU Syllabus \\
Term II & Organization Behavior II & \\
(Sep. 1-Dec. 31) & Research Methodology & \\
& Management Accounting & \\
& Corporate Database Management & As per CU Syllabus \\
& Managerial Economics II & \\
& Marketing I & \\
Term III & Foundations of Services Management & \\
(Jan. 1-Mar. 31) & Humanes Law Resources Management \& Industrial Relations & \\
& Management Information Systems & \\
\hline
\end{tabular}

Table 4

Proposed CU-VCU Component

\begin{tabular}{lll}
\hline Terms & Courses offered & Comments \\
\hline Term III(a) & Internship & VCU and CU faculty \\
April 1-May 30 & & joint participation \\
Term IV & TBD & VCU and CU faculty \\
June 1-Aug. 31 & joint participation \\
\hline
\end{tabular}


Table 5

Proposed VCU Component

\begin{tabular}{llc}
\hline Terms & Courses offered & Comments \\
\hline Term V & TBD & VCU faculty \\
Fall Semester & & \\
Sep. 1-Dec. 15 & TBD & VCU faculty \\
\hline Term VI & & \\
Spring Semester & & \\
\hline
\end{tabular}

Table 6

Summary-Proposed Program Delivery Schedule Involving Both CU and VCU

\begin{tabular}{llll}
\hline Date & Courses & Classes & Place/Location \\
\hline April 1-May 30 & Internship & 1 & CU-VCU (virtual or at CU) \\
June 1-Aug. 30 & TBA & $1 / 2 / 3$ & CU-VCU (virtual or at CU) \\
Sep. 1-Dec. 15 & TBA & $3 / 4$ & VCU \\
Jan. 15-May 15 & TBA & $3 / 4$ & VCU \\
Total-One Year & MS Degrees & 10 & CU-VCU \\
\hline
\end{tabular}

\section{Entrepreneurial Program Tuition Agreement (EPT)}

A key ingredient to the successful implementation of this partnership and program was a 5-year Entrepreneurial Program Tuition Agreement (EPT) signed by the president of VCU and the dean of the VCU School of Business. The EPT specifies two critical dimensions necessary for the long-term viability of the program, including: (1) allowing a cohort group of CU (Indian) graduate students accepted into the CU-VCU MBA/MS program to pay a different (lower) tuition rate than that required of other "out-of-state" students, and (2) allowing the VCU School of Business to retain the majority of the tuition revenue. These two EPT dimensions have allowed the VCU School of Business to offer a unique value proposition to Indian graduate students and to ensure its source of funding.

This program started in June of 2010 with the enrollment of 60 Indian students. Both VCU and CU expect this number to grow to 100 to 150 students in the future.

\section{Conclusion}

Globalization is not simple the transfer of work to emerging economies. Globalization is an art of human relations that, like other arts, is premised on insights gleaned from teaching and from experience, and honed by continual practice, day in and day out, in the executive suites of the world's corporations. Globalization concerns the exercise of management and leadership on a worldwide scale. Global business is not the sole preserve of large companies. For small and medium-sized enterprises, too, it is neither a theory nor a discussion point, but a fact of life. (Andrews \& Tyson, 2004, pp. 4-5).

Will the VCU-HU EMBA program proposed for Cairo and the VCU-CU MBA/MS proposed for Bangalore, India be successful? Will the programs meet the challenges of providing an impactful higher education option for rising executives and managers in the Arabic region (Egypt and beyond), and India? Will our efforts provide an example that can be emulated by others such that the business class of professional managers in the Arabic region and India (capable of competing effectively in today's global environment) can be further augmented and make significant future strides in each region' economic and social progress? Will the programs further globalize the 
management class in the Middle East and India and allow these regions to further prosper in today's interconnected economies?

The need is clearly there, but whether the administrative, governmental and markets forces will respond to the innovative educational products that VCU, HU and CU are offering, remains to be seen. The VCU-HU EMBA in Cairo and VCU-CU MBA/MS in Bangalore, while priced competitively to reflect the economic realities of both regions will not be inexpensive nor lack rigor. Time and the market will soon let all involved know if these effort will be successfully implemented and viable over the long-run.

In conclusion, beyond whether these specific programs are successful or not, it is the issue of globalization and the development of individuals, nations, societies and regions in the world. Education, particularly higher education, will play a key if not the key role in such development. When future opportunity and positive vision for growth and prosperity are collectively shared by any country or region, then indeed prosperity and perhaps peace may have a chance of thriving. This is the central premise of this paper and the driving forces behind the VCU-HU, VCU-CU partnership efforts to develop and implement truly globally focused programs of business higher education. We are all cautiously optimistic.

\section{References}

Agarwal, S. (2009, September 6). An overview of education market in India. Retrieved from http://www.sramanamitra.com/2009/09/06/an-overview-of-the-education-market-in-india/

Akkari, A. (1999). The construction of mass schooling: A two-tiered educational system. Education and Society, 17(1), 37-51.

Akkari, A. (2004). Education in the Middle East and North Africa: The current situation and future challenges. International Education Journal, 5(2).

Ali, A. J. (2000). Globalization of business: Practice and theory. Binghamton, N.Y.: International Business Press.

Altbach, P. G. (2010, April 7). India's open door to foreign universities. The Hindu. Retrieved from http://www.thehindu.com/opinion/lead/article391080.ece?homepage=true

Andrews, N., \& Laura D’Andrea, T. (2004). The upwardly global MBA. Working Paper, London Business School.

Basu, K. (2006, August 18). India's faltering education system. BBC News UK.

CNN-IBN. (2008, August 10). SC upholds OBC quota, keeps creamy layer out. IBN Live.

Jayaprakash, N. (2009, August 1). Private engineering and medical colleges making a killing. Deccan Gazette.

Fergany, N. (1995). Strategic issues of education and employment in Egypt. Cairo: Al-Mishkat Center for Research and Training.

Friedman, T. L. (1999). The lexus and the olive tree-Understanding globalization. New York: Anchor Books.

Friedman, T. L. (2005). The world is flat-A brief history of the twenty-first century. New York: Farrar, Straus and Giroux.

Garten, J. E. (2006, December 09). Really Old School. The New York Times. Retrieved from http://www.nytimes.com/2006/12/09/opinion/09garten.html?scp=1\&sq=Nalanda\&st=cse

Gould, W. T. S. (1993). People and education in the third world. London: Longman.

Institut National de'études statistiques. (1999). Recensement de la population et de l'habitat. Tunis: INES.

Khemka, V. (2006, September 6). Teacher salaries in India. The Red Pencil.

Klein, N. (2001). No logo: Taking aim at the brand bullies. USA: Picador.

The Middle East Policy Council, and The Stanley Foundation. (2008, June 10). Congressional Policy Brief \#5. US challenges and choices in the Gulf: Economic liberalization.

OIFC. (2010, March 16). Foreign educational institutions bill cleared by cabinet for introduction in parliament. Retrieved from http://www.oifc.in/Article/Foreign-Educational-Institutions-Bill-cleared-by-Cabinet-for-introduction-in-Parliament

Rosensweig, J. A. (1998). Winning the global game: A strategy for linking people and profits. New York: The Free Press.

Said, E. W. (1993). Culture and imperialism. New York: Knopf.

Sarva Shiksha Abhiyan. (2010). Ministry of human resource development, government of India. Retrieved from http://education.nic.in/ssa/ssa_1.asp

Seethalakshmi, S. (2009, June 29). China overtakes India in Ph.D.s, too. The Times of India. 
Sharma, V. (2010, November 20). Is higher education in India no good? Retrieved from http://www.youthkiawaaz.com/2010/11/is-higher-education-in-india-no-good/

Sheikh, A. (2010, May 23). India’s education market projected at \$ 50 Bln by 2015: Assocham. MyNews.

Surapaneni, N. (2005). Corruption in India. Centre for Media Studies. Retrieved from http://infochangeindia.org/governance/features/-if-the-politicians-are-corrupt-so-too-will-be-the-people.html

UNICEF. (2000). State of the world's children 2000. New York: UNICEF.

UNICEF India. (2006, April 24). Global campaign for education-More teachers needed. Retrieved from http://www.unicef.org/india/education_1551.htm

Web log message. (2009, July 08). The True Meaning of Matha Pitha Guru Deivam. Retrieved from http://vjai.com/post/138149920/the-true-meaning-of-matha-pitha-guru-deivam

Wikipedia. (2010). Indian Schools of Business. Retrieved from http://en.wikipedia.org/wiki/Indian_School_of_Business

Watkins, K. (1999). Education now: Break the cycle of poverty. London: OXFAM.

Wood, Van R., \& Ahmed, M. (2004). Globalization and the state of health care worldwide: Views from both sides of the debate. In Proceedings of Association of Health Care Research Conference, Breckenridge, Colorado, March 17-20.

World Bank. (2003). Claiming the future. Choosing prosperity in the Middle East and North Africa, Washington, D.C.: The World Bank. 